This item was submitted to Loughborough's Research Repository by the author.

Items in Figshare are protected by copyright, with all rights reserved, unless otherwise indicated.

\title{
The Olympics and Japanese national identity: Multi-layered otherness in Tokyo 2016 and 2020
}

PLEASE CITE THE PUBLISHED VERSION

https://doi.org/10.1080/18692729.2019.1607137

\section{PUBLISHER}

(C) German Institute for Japanese Studies. Published by Taylor and Francis

\section{VERSION}

AM (Accepted Manuscript)

\section{PUBLISHER STATEMENT}

This is an Accepted Manuscript of an article published by Taylor \& Francis in Contemporary Japan on 30 Apr 2019, available online: https://doi.org/10.1080/18692729.2019.1607137

\section{LICENCE}

CC BY-NC-ND 4.0

\section{REPOSITORY RECORD}

Tamaki, Taku. 2019. "The Olympics and Japanese National Identity: Multi-layered Otherness in Tokyo 2016 and 2020”. figshare. https://hdl.handle.net/2134/37574. 


\title{
The Olympics and Japanese National Identity: Multi-layered Otherness in Tokyo 2016 and 2020
}

\author{
Taku Tamaki, PhD \\ Politics and International Studies (POLIS) \\ School of Social Sciences \\ Loughborough University \\ Loughborough LE11 3TU \\ UNITED KINGDOM \\ E-mail: T.Tamaki@lboro.ac.uk
}

Taku Tamaki is a Lecturer in International Relations in the School of Social Sciences at Loughborough University in the UK. He has written widely on the issues of Japanese foreign policy, Japanese national identity, and the international politics of the Asia-Pacific region. He has published in journals such as The Pacific Review, International Relations, and the International Relations of the Asia-Pacific.

Acknowledgements: I thank the editor and the reviewers for their helpful comments. I also thank the participants at the Nordic Association of Contemporary Japanese Study conference at the Norwegian University of Science and Technology in April 2016 for their helpful comments on an earlier draft of this article. I also thank the Institute for Asian Cultural Studies at International Christian University in Tokyo for enabling me to do some of the research. 


\title{
The Olympics Narratives and Japanese National Identity: Multi-layered Otherness in Tokyo 2016 and 2020
}

\begin{abstract}
How are Japanese identity narratives constructed in the Tokyo 2016 campaign and the Tokyo 2020 bid and organisation? The earlier narratives of Tokyo 1940 and 1964 bids entailed invoking the Western Otherness to emphasise Japan's Asian affinity while simultaneously emphasising Japan's un-Asian characteristics, effectively employing dual Otherness to tell the story of Japanese Self. Tokyo's position as a global city today means that Japanese Self is now constituted through multiple Otherness involving the West, Asia, as well as the primacy of Tokyo in opposition to the relative neglect of the periphery, constructing a more complex story of Otherness. There are concerns Tokyo is hoarding infrastructure investment ahead of Tokyo 2020, just as the regions affected by March 2011 disasters require capital infusion, fuelling a sense of Tokyo versus the rest. Hence, on top of the residual dual Otherness that can still be witnessed, Tokyo 2020 grafts another layer of Otherness, this time at the domestic level. In this article, I explore identity narratives by policy elites and opinion leaders to show the complex nature of multi-layered Otherness in the Tokyo 2016 and 2020 bidding and organisation.
\end{abstract}

Key words: Japan, the Olympics, National Identity, Tokyo 2016, Tokyo 2020

\section{Introduction}


The Olympic Games are opportunities for the hosts to tell a story of its collective sense of national identity. Tokyo's ill-fated 1940 Olympics campaign leveraged the universalising ideal of the Olympic Movement: that the Olympic Games could not be universal unless they were held in a non-Western state. The organisers of Tokyo 1964 highlighted modernity and reconstruction to emphasise the resurrection of postwar Japan. In both Tokyo 1940 and 1964, the bid narratives portrayed Japan as a nonWestern nation and as an un-Asian entity, framing Japanese Self in opposition to the dual Otherness of West and Asia. Today, the context has changed significantly. Tokyo has become a global city, while its pre-eminent position is challenged by other megacities in East Asia, prompting the organisers of Tokyo 2016 campaign and Tokyo 2020 bid and preparations to persuade the International Olympic Committee (IOC) that Japan, as a technologically advanced economy, is best equipped to become the benchmark for a new, sustainable, Olympics in East Asia.

How are the narratives of Japanese identity in the Tokyo 2016 bid and the Tokyo 2020 bid and organisation constructed? What happened to the dual Otherness witnessed in Tokyo 1940 and 1964? The residues of dual Otherness remain, but the narratives in the Tokyo 2016 campaign and particularly the Tokyo 2020 bidding and organisation indicate that the re-articulation of Japanese Self involves multi-layered identity construction - marked by the tensions between Tokyo as a global city hoarding infrastructure investments, and the marginalised regions having have to compete with Tokyo for attention - creating a more complex story of Otherness. This paper explores Japanese national identity construction represented mainly through the elite narratives of Tokyo 2016 and 2020. Globalisation and IOC's sustainability agenda means that the dual Otherness has been diluted and superseded by a more complex multi-layered Otherness in which the West and Asia cease to be prominent. 
The narratives of Japanese Self within the Tokyo 2016 bid and the Tokyo 2020 bid and organisation still do involve the residues of dual Otherness, whereby Japan's technologically-advanced Self is narrated in counter-distinction to a generalised Otherness, while singling out the Asian Otherness in the process. But, for Tokyo 2020 in particular, the cohabitation of residual dual Otherness with the increasing prominence of domestic dissent against the official story of the Games exemplifies that the internal Otherness is becoming equally potent as - if not more pronounced than - the external dual Otherness for those detractors who harbour misgivings about hosting the Olympics.

This article is divided into four sections. The first section very briefly discusses the analytical procedure of this article, by discussing the discursive nature of identity and the role sport plays in rearticulating a sense of national identity, while I simultaneously describe the criteria for selecting sources and statements. The second section explores the literature on Japanese identity narratives during the previous Olympic campaigns altercasting the West and Asia into a dual Otherness against which the purported Japanese uniqueness is anchored. But the changes to the international environment made dual Otherness less prominent, especially in the context of Tokyo becoming a global city. The third section discusses the Tokyo 2016 bid which focused on telling a story of technologically-advanced Japanese Self in contradistinction to a nebulous generalised Other and with a hint of Asian Otherness. In the final section, I focus on the narratives of Tokyo 2020 bidding and organisation, showing how the stories of Otherness became multi-layered. Reconstruction following the March 2011 disaster (hereafter 3/11) and the enthusiasm for new infrastructure projects to address IOC's sustainability agenda are considered an opportunity to showcase Tokyo's technological knowhow. But spiralling costs and the 
resultant sense of affluent Tokyo amassing infrastructure investment while the money-strapped periphery is being ignored indicate that dual Otherness has been superseded by a more complex multi-layered Otherness.

\section{Identity Narratives of Self}

Identity is difficult to analyse, as the only viable way to discern its presence is through the stories of relationship between the Self and Other. Margaret Somers and Gloria Gibson (1994, p. 61) argue that the Self distinguishes itself from the Other through narratives that '[embeds] identities in time and spatial relationship', locating the Self in opposition to the Other in a "“societal" context' (Somers and Gibson, 1994, p. 69). Rogers Brubaker and Frederick Cooper (2000, p. 5) note that 'one can analyse "identity-talk" and identity politics without, as analysts, pointing to the existence of "identities", a notion most eloquently utilised by Benedict Anderson (1991, pp. 1519), who suggests that language assumes power when they help construct collective identities. For Anderson (1991, p. 37), the spread of vernacular language books helped permeate common ideas and a collective sense of identity in what he termed the 'imagined community'. Anderson (1991, p. 133) argues that the importance of language lies in 'its capacity for generating imagined communities, building in effect particular solidarities'.

It is through the constructions of Otherness that we become aware of the Self. Hence, the representations of Otherness are good indicators of how a community reaffirms its own uniqueness. As Douglas Porpora (1997, p. 253) points out, '[u]niqueness is integral to identity' and that 'identity is, thus, linked to 
differentiation'. David Campbell (1998, p. 9) posits that constructing the Self/Other dichotomy is very much a human condition, claiming that 'identity is an inescapable dimension of being. No body can be without it'. It is as if we cannot be without identity which is 'constituted in relation to difference', but 'difference is [also] constituted in relation to identity' (Campbell, 1998, p. 9). Hence, a community is always in search of the Other in an effort at defining the Self (Campbell, 1998, p. 23). But the Self/Other dichotomy is not static: it transforms over time, adjusting to changes in social context (Somers and Gibson, 1994, pp. 61-62).

This sense of imagined communities and the constant search for Otherness is particularly emphasised during international sporting events, as spectators cheer 'their' national team competing against the numerous Others. John Bale (1986, p. 18) suggests that the sporting event 'is, after war, probably the principal means of collective identification in modern life. It provides one of the few occasions when large, complex, impersonal and functionally bonded units such as cities or countries can unite as a whole'. Bale (1986, p. 18) suggests that participants in 'international sports represent nations' providing a fertile ground upon which people imagine a common nationhood. Indeed, 'events like the Olympic Games or the World Cup mould people's impression of participating nations and nationalities' (Bale, 1986, p. 24). Joseph Maguire (1994, p. 405) also argues that '[s]port synthesized people's habitus with the ongoing invention of political and social traditions to provide the medium for and barometer of national identification and competitive community struggle'. Nations and states represented through international sporting competition conjures a shared sense of we-feeling among the spectators in which '[m]ultiple identities - of which national identity is a key feature - are constructed by a process of cultural representation', particularly through the use of 'national flag, anthem, and 
emblem' (Maguire, 1994, p. 410). In a similar vein, Barrie Houlihan (1997, p. 122) identifies the power of sport to reinforce a sense of belonging to an imagined community suggesting that 'the national team is a valuable metaphor for the nation'. Simultaneously though, the representation of Self in international sporting events rely on the constant search for the Otherness, almost to the extent that the identification of Otherness is prioritised over the recognition of Self (Maguire, 2011). It is as if a nation is in constant search of the Other as a way to establish a concrete sense of Self (Ward, 2009). Hence, sport is an opportune locus upon which the imagined Self and the stories of Otherness are shared by the populace.

In this article, I focus on sources such as official statements and publications, as well as statements and interviews by elites along with opinion leaders, appearing in newspapers, magazines, and online media to fathom the elite language within the Tokyo 2016 bid and the Tokyo 2020 bid and preparation. These narratives point to a shared story of Japanese uniqueness within elite circles that reproduce a variety of Otherness including: Asia; the West; the nebulous generalised Other; and the periphery in opposition to Tokyo enjoying the focus of attention. The ideas of elites constitute dominant narratives that feed into the official story-telling of bidding and preparing for the Olympics around which the wider populace purportedly coalesce around a sense of an imagined Olympics community. I show how the Japanese Self was narrated in opposition to both the Western and Asian Otherness in Tokyo 1940 and 1964 in what I call dual Otherness, while the narratives of Tokyo 2016 demonstrate a steady erosion of dual Otherness in favour of sustainability. As John Horne and Wolfram Manzenreiter (2012, pp. 106-7) point out, 'acknowledgement of [one's] own tradition' remains equally important as participating in the international Olympics competition today-something Tokyo 2016 has done through the language 
of high-tech and sustainability. However, by Tokyo 2020, the residues of dual Otherness are further subdued, as the dissenting voices inside Japan refuse to embrace the official story of the 2020 Games, indicating that the official narratives focusing on external Otherness are steadily losing their persuasiveness. I say 'residues' of dual Otherness because a hint of generalised Other, as well as the Asian Otherness can be seen amidst the emergent dichotomy of Tokyo versus the periphery. It is as if the relatively straight-forward dual Otherness of Tokyo 1940 and 1964 has been superseded by a more complex, triple Otherness, spanning both the international and domestic levels in Tokyo 2020.

\section{Japanese Self vs. the Dual Otherness in the Previous Olympic Bids}

In her study of the Tokyo 1940 bid, Sandra Collins (2007a, p. 956) argues that 'the Japanese state made alluring relationships between its definition of national culture and the Olympics that further justified the emerging rhetoric of Japan as the liberator of Asia in the 1930s'. She (2006, p. 1130) suggests that the 1933 campaign booklet portrayed Japan as a 'visual puzzle of the old within the new and the West within the East.... As a unique nation state that embodies both the East/West and the old/new ... as a rare montage of the old within the new'. This recourse to nativism and the depiction of Japan as a cohabitation of old with the new-and the East with the West—indicated Asia as an awkward and premodern Otherness in contra-distinction to the Japanese Self that was a modern, yet non-Western, entity. Collins (2007a, p. 959) notes that the 'IOC support also publicly confirmed the opinions of Japanese ideologues who considered Japan to be the only Asian nation capable of participating and contributing equally to the world order that had been predominantly dominated by the West'. 
In a similar vein, Ikei Masaru (2016, p. 5) suggests that Tokyo 1940 was considered to be an opportunity for Japan to distinguish itself as a pioneer in universalising the Olympics movement, as well as to secure the prosperity of the imperial capital. Like Collins, Ikei (2016, p. 7) points out that the organisers distributed an English-language pamphlet, Japan Pictorial Interpretation, towards the end of the 1932 Los Angeles Olympics; and in anticipation for the 1935 Oslo IOC meeting, the organisers accelerated their campaign by distributing among IOC members a photo album, Sports Center of the Orient, to emphasise Japanese exoticism as a uniquely non-Western, yet un-Asian nation. Ikei (2016, p. 12) adds that the success of Japanese athletes at the 1936 Berlin Olympics, right after Tokyo was selected to host the 1940 Games, provided another indication that Japan, as a nonWestern nation, was an 'Asian sporting super power', distinguishing it from the rest of Asia as well. But as Christine Sell (2007, p. 41) argues, 'the size and scope of an Olympiad probably were not within Japan's grasp at that time', as evidenced through chaotic organisation. Sell $(2007$, p. 43) notes that the IOC tried to coax Japan by pointing out that the failure 'to present the Games in Tokyo' would mean 'a failure for all of Asia, since the Games would not be presented again anywhere in Asia for many years to come' which would be 'a very real loss of prestige of Japan'. Consequently, the wisdom of the Tokyo bid was questioned, and the government forfeited the Olympics on 1 July 1938.

Dual Otherness was evident in the bid narratives for Tokyo 1964 as well. According to Tagsold (2010, p. 294), the protracted negotiations between the Tokyo 1964 organisers and the US military over land acquisition, particularly in the centre of Tokyo, amounted to a collective exorcism of the memories of War, suggesting that, '[t]he Games were not simply about denying or forgetting the past; they were as much 
about finding the right track to fulfilling the promises of modernity which had been lost from sight during the ultra-nationalist era'. Japan's rapid economic development from the mid-1950s betrayed Japanese confidence in being the only Asian nation to achieve such an economic status. As Taniguchi Gentarō (1997, p. 42) writes,

Ever since the First Asian Games were held in New Delhi, Japanese athletes exhibited their sporting prowess, resulting in the shared idea that Japan was the most advanced sporting nation in Asia, encouraging it to focus more on catching up with the West. It is not surprising that the Asian sporting community felt that 'Japan is not an Asian country' any more.

Noriko Aso (2002, p. 15) also notes that, '[t]he argument put forward by the Japanese delegation [to the 1959 Munich IOC session] that the Olympics could not be truly considered international until the event had been held in Asia proper had considerable force'. Suzuki Yoshimasa (2013, p. 69) claims that Tokyo 1964 was a vehicle for filling a 'psychological vacuum' (seishin-teki kühaku) and for regaining national pride and dignity through pacifism, development, and modernity. And as Tagsold (2009, p. 2) notes, the image of athletes competing to win gold medals for the nation in Tokyo 1964 helped to '[restore] national pride', given the purported sanctity of sport as an uncontroversial expression of nationalism in postwar Japan.

\section{Changing Identity Representation Under Globalisation}

Today, globalisation poses a challenge to identity representation, and Saskia Sassen's (1995) notion of global city is interesting here because of the changing relation of place and identity. A global city, like Tokyo, is a beneficiary of globalisation: location 
is increasingly irrelevant given the ease with which information flows across borders, thanks to information technology. However, Sassen (1995, p. 32) also found that '[g]lobal economy materializes in concrete processes situated in specific places', with a 'considerable place-boundedness' (Sassen, 1995, p. 35). Despite potential changes to the way imagined communities are constituted in response to globalisation, the primacy of 'place' suggests the potency of identity narratives rooted to a particular location.

Tokyo as a global city thrives on globalisation, but the idea of place remains important. Tokyo benefits from the network effect whereby people and organisations are attracted to the metropolis as a place because so much activity is concentrated in it (Sassen, 2016). But as long as an idea of place remains relevant, identity narratives can retain its original structure, particularly as globalisation saw China and South Korea emerge as rivals to Japan. The growth of megacities such as Beijing, Shanghai, and Seoul meant that Tokyo ceased to be the pre-eminent urban centre in East Asia, prompting policy elites in Japan to search for new ways to distinguish Tokyo from its Asian rivals.

The demands of organising a modern, sporting mega-event points to a further transformation of identity narratives. The tightness of bidding protocol, the extended bid horizon, and the centrality of globalism force identity narratives to change. Manzenreiter (2006, p. 151) suggests that, within the current globalised context, 'sport spectacles simultaneously can provide grand theatre and secular ritual, popular entertainment and communal festival'. While modern Olympic bidding requires addressing increasing pressures from the IOC on issues such as sustainability, the centrality of location still leaves room for the elaboration of Self/Other dichotomy. For Manzenreiter (2006, p. 157), sporting events remain a locus for the 'playful 
representation' of national identities. As William Kelly (2011, p. 2263) points out, there is 'an Olympic temporality of extended, overlapping and interpenetrating cycles' as experienced through Tokyo 2016. Kelly (2011, p. 2267) suggests that Tokyo 2016 organisers were under immense pressure to appeal 'to the growing significance of East Asia as a region, economically and ideologically, in the IOC's vision of the Olympic future'. In a similar vein, Andreas Niehaus and Christian Tagsold (2011, p. 406) also point out that there is still the urge to define 'Japaneseness' within the context of globalisation, and according to John Horne and Manzenreiter (2012, p. 115), the globalising forces of modern Olympics militate against the geographically-bound identity representations of host states.

Hence, dual Otherness remains_-but only as residues. Kelly (2009, p. 1) argues that the symbol for Tokyo 2016-the musubi logo-represented the "mission to unite ... old and new Japan', and that 'Japan still feels that the region is less than fully acknowledged by the IOC and the Olympic Movement' and Tokyo 2016 was about shoring up Japan's 'international prestige' (Kelly, 2009, p. 2). Kelly (2009, p. 3) also emphasises the characteristics of contemporary Olympics involving a 'long bidding process', and 'intensive infrastructure construction', while the Games themselves constitute a 'brief frenetic moment', along with the requirement for the 'project of legacy-making'. But he $(2009$, p. 3) adds that, '[t]he Olympic movement is really a crucible of localism, nationalism, regionalism, and globalism'. Horne and Manzenreiter (2004, p. 195) also point out that, despite the changing economic and social environment, sporting mega-events still provide an outlet for a 'safe form of expressive nationalism' and a 'rare opportunity to overcome the diffidence many people had felt about overt displays of nationalism and expressions of national identity since $1945^{\prime}$. 
But Tokyo's status as a global city elicits alternative stories of Otherness to emerge. Horne and Manzenreiter (2012, p. 109) argue that cities need to invest in 'iconic architecture and urban spaces' to 'flag their presence in the world', whereby sporting mega-events increasingly required the state to embrace construction lobbies, often encouraging cronyism (Horne and Manzenreiter, 2004, pp. 190-91). Within this context, the IOC and multinational corporations emerged as 'transnational actors' to which the organisers must emphasise the merits of hosting the Olympics. Here, dual Otherness remained as residues, whereby organisers sought to differentiate Tokyo from other Asian cities, as well as other non-Asian candidates. Simultaneously, there was now an emphasis on the language of universalism and globalism as the focal point of the modern Olympic movement (Horne and Manzenreiter, 2012, pp. 114-16); and concentration of infrastructure investments around Tokyo prompted questions about fiscal priorities. This is particularly the case, given major public works projects became a pre-requisite, and in the case of Tokyo 2020, stressing the need for reconstruction after 3/11 was considered a winning formula (Nishiyama, 2015, p. 5)

The pressures for infrastructure investment especially for Tokyo 2020 meant that a third dimension of Self/Other dichotomy became relevant — that of Tokyo's role as a global city hosting the mega-event versus the periphery. Abe Kiyoshi (2016, pp. 66-67) notes that the 'decisive difference between Tokyo 2016 and $2020 \ldots$ is that the reconstruction [after 3/11] became the main driver for the bidding and organising of the 2020 Games'. Abe (2016, p. 67) suggests that there are two facets to Tokyo 2020: (1) boosting employment and productivity; and (2) to show the world that Japan is back. Yet, 'it remains unclear how hosting the Olympics in Tokyo will contribute to the reconstruction of the Tohoku region, particularly as the construction sector is concerned', since Tokyo as a global city will remain the predominant centre of 
economic activity (Abe, 2016, p. 67). Abe (2016, p. 76) points out that there is a serious transparency and accountability deficit in Tokyo 2020, and that the Olympics preparation has developed into a 'syndrome' $(s h \bar{o} k \bar{o})$ in which the interests of the select few determine the investment priorities. The narratives of Tokyo 2020 reveal the complex characteristics of multi-layered Otherness today.

\section{The Narratives of the Tokyo 2016 Bid}

Tokyo's bid to host the 2016 Olympics started in 2005. The organisers stressed Tokyo's maturity as a modern metropolis in defining the new criteria for sustainable Olympics in East Asia, a story designed to distinguish Tokyo from other Asian global cities, especially now that Tokyo ceased to be the pre-eminent metropolis in the region. The image of fair play associated with sport was recast into a message of Tokyo's gift to the world (Koshiishi, 2008, pp. 20-21) - a unique, environmentally sustainable, contribution to the future of the Olympics movement that only Tokyo as a global city can provide.

The story of the Tokyo 2016 bid focused on how the city has moved on from 1964 to become a mature, sustainable metropolis with a global appeal. The Governor of Tokyo, Ishihara Shintarō, stated in September 2005 that the bid to host the 2016 Olympics was aimed at portraying Tokyo as a 'mature city re-establishing Japan's position in the world' (TOCOG, 2010, p. 4). A report on the bidding process (the Bid Report) published in 2010 by the Tokyo Organising Committee for the Olympic and Paralympic Games (TOCOG) contained a further set of symbolisms in an attempt at moving beyond the memories of the 1964 Games. Numerous references were made to Tokyo as a 'mature' (seijuku shita) metropolis building on the legacies left by the previous Olympiad. In the same September 2005 speech, Ishihara stated that, 'it has 
been 40 years [since the last Olympic Games], and since then, Tokyo has developed into a metropolis that is unprecedented in the world' (TOCOG, 2010, p. 5). The Game's 'compact scale, the refurbishing of existing facilities, and a low environmental impact and energy footprint' (Kelly, 2009, p. 5) was a subtle pointer to distinguish Tokyo from Beijing 2008. As Kelly (2011, p. 2264) observes, it was a story underpinned 'by a national anxiety about the political and economic challenge of its rival East Asian superpower, China'.

The March 2006 Resolution by the Tokyo Metropolitan Assembly couched the story within the language of pacifism, resolving that 'the chance to host another Olympics in Tokyo 50 years since the previous one represent our wish to nurture world peace [sekai heiwa]' (TOCOG, 2010, p. 9). Just as Tokyo 1964 signified peace and reconstruction, the Tokyo 2016 bid symbolised peace and maturity. The campaign included subtle references to Japan's collective postwar identity of pacifism emphasised through the decision to enlist the cities of Hiroshima and Nagasaki in the national awareness-raising campaign, in an attempt at reinforcing Japan's uniqueness as a pacifist state (TOCOG, 2010, p. 93).

Focus on the sustainability agenda was beginning to supersede dual Otherness - while the language of peace remained conspicuous. The Bid Report summarised the bidding process as showcasing Japan's successful postwar reconstruction, 'uniting the world by working towards promoting peace in the world' (TOCOG, 2010, pp. 342-43). The Deputy Governor of Tokyo, Inose Naoki (2011), stated in an online column that he was initially less enthusiastic about hosting another Olympic Games in Tokyo, but the more he was exposed to the campaign, the more he became convinced of the merits of 'Tokyo promoting a model for a mature metropolis'. For him, there was the imperative of addressing the IOC's preference for 
sustainability, as well as emphasising Tokyo as a globally attractive destination for foreign investment. Inose (2011) suggested that Tokyo 1964 was the 'Olympics of a developing state' (hatten tojō-koku no orinpikku), while the 2016 bid aspired to become the 'Olympics of a developed state' (senshin-koku no orinpikku), and he was hopeful that Tokyo 2016 would act as 'a platform for Tokyo to demonstrate a vision of the future to the world'.

\section{The Withering Away of Dual Otherness}

The residues of dual Otherness are now firmly couched within the context of sustainability as the predominant theme. Governor Ishihara suggested in September 2005 that 'the combination of [Japanese] high-tech skills, along with the accumulation of a variety of history and culture, along with sports, will enable us to present [in Tokyo 2016] a uniquely Japanese set of values' (TOCOG, 2010, p. 5). The Bid Report emphasised this uniqueness by identifying Tokyo 2016's concept to be 'the Games where participants can enjoy the spirit of hospitality and Japanese culture' (TOCOG, 2010, p. 15). The Bid Report also mentioned the 'Japanese spirit of hospitality [omotenashi no kokoro]' (TOCOG, 2010, p. 72) as something with which Japan can be proud. Furthermore, in addressing the IOC's theme of sustainability, Ishihara argued in June 2008 that 'Japan's beauty and Tokyo's attractiveness' provide 'a new

form of Olympics made possible precisely because of Japan's technological knowhow' in becoming 'a beacon of peace and environmental sustainability' (TOCOG, 2010, p. 72). Similarly, a former secretary to the Tokyo Governor, Takai Hideaki, wanted Tokyo to highlight its maturity and to set an example for the rest of East Asia. For Takai, if China and South Korea wanted to host another Olympics, then Tokyo will become the gold standard against which their success should be 
judged (Uesugi, 2013, p. 142). The Bid Report added that the new Olympic stadium will become the hub of Asian sports (Ajia no spōtsu kyoten), while the president of Tokyo Chamber of Commerce, Okamoto Tadashi, stated in 2009 that 'the economic impact of the Olympics will be felt not only in Japan, but will be felt in other Asian countries as well' (TOCOG, 2010, p. 355).

The residues of dual Otherness were employed to emphasise Tokyo's sustainability credentials. During the October 2008 meeting of the Asian Olympics Committee (OCA) in Bali, the Japanese IOC delegation sought support from fellow Asian IOC members by reassuring that Japan was a 'member of Asia' (Ajia no ichiin), and that 'Asia remains a priority' (Ajia-jūshi) (TOCOG, 2010, p. 158). Furthermore, TOCOG (2010, p. 209) reassured the IOC delegation in April 2009 that Japan was 'proactively engaged as a permanent member [of the World Anti-Doping Agency] representing the Asian region'. Simultaneously, Tokyo's distinctiveness from the rest of Asia was invoked again in an attempt at strengthening Japan's case in 'hosting new Olympic Games that only Japan can organise [Nippon dakara dekiru, atarashii orinpikku]' (Spobiz, 2011). Furthermore, in a response to a questionnaire from the IOC Evaluation Commission, TOCOG stated that,

The gift which Japan, as host for 2016, would then be able to return to the world would be the first major example and model of which other countries in Asia and the world could draw as they move into the future.... The gift would, indeed, become a gift from the international Olympic movement and would build upon the movement's already strong commitment to sustainability by extending this across national borders and beyond the environmental dimension (Shimizu, 2014, p. 605; emphases added) 
The Tokyo 2016 bid failed; but this trend to prioritise sustainability over dual Otherness accelerated in Tokyo 2020, particularly as the aftermath of $3 / 11$ meant infrastructure investment became an imperative.

\section{Tokyo 2020 and the Multi-layered Otherness}

The narratives of the Tokyo 2020 bid and organisation differ from those of the Tokyo 2016 campaign with the language of reconstruction at the fore (Abe, 2016, p. 66). Ishihara felt it opportune to declare Tokyo's candidacy for the 2020 Olympics in April 2011 as a way for Japan to regain genki ('vitality') through reconstruction (Abe, 2016, pp. 66-67). Tokyo 2020 was regarded as an international stage for Japan to show the world that it has come back, and as a way to show gratitude for the help Japan received after 3/11 (Abe, 2016, p. 67). Ishihara considered it a national duty to campaign for the 2020 Games, arguing that the necessary transformation of Japan and the resurrection of national prestige must originate from Tokyo (Uesugi, 2013, pp. 136-37). Ishihara understood the imperative of addressing the IOC bidding protocol, pledging to exhibit Japanese technology for sustainability (Uesugi, 2013, p. 138). As Hara Eiji (2015), an activist, points out, the purported legacies of Tokyo 2020 included the promotion of high-quality Japanese-style medical practice, as well as promoting Japan as a 'tourist state' (kankō-rikkoku), reiterating Japan's perceived uniqueness as an unrivalled technological superpower in East Asia. Ōno Shin (2014, p. 63) suggests that Japan should exploit Tokyo 2020 as a 'show window' for innovation by introducing new technology to address Japan's aging society, as there are clear potentials for Japanese businesses to exploit such technology in the Asian markets. 
The 2020 Tokyo bid had a discernible nationalist undertone while simultaneously telling the story of Tokyo as a mature metropolis. The lessons of the failed Tokyo 2016 bid and the theme of reconstruction framed Tokyo 2020 as a vehicle for boosting the national economy, since Japan's international prestige was perceived to be at stake following the 'lost decades'. Furthermore, the image of sport as encouraging fairness and diligence provided a fertile platform to present Tokyo 2020 as reflecting a purportedly distinct Japanese work ethic and hospitality (Ikei, 2016, p. 29). An idea of fair play associated with sports provided an innocuous outlet for nationalism.

The Tourism White Paper (Tourism Agency, 2014, p. 43) reiterated Japan's purported cultural uniqueness by claiming that the Olympics would be a 'great opportunity to express the country's culture and appeal'. The Olympics were seen as an 'opportunity for Japan to reaffirm its national identity', as well as an occasion to display post-3/11 national unity (Suzuki, 2013, p. 43). While the 2020 campaign started as a brainchild of Ishihara in his bid for re-election to the Tokyo governorship, the imperative of national reconstruction ensured that the central government was involved from the outset, anxious to allay fears over safety following the Fukushima Daiichi nuclear reactor meltdown. Prime Minister Abe Shinzō reassured IOC delegates at the Buenos Aires meeting in September 2013 that Japan remained safe, arguing that 'Tokyo has been given a big chance to shine at the centre of the world', pledging to "use the Olympics to provide an impetus for overcoming the deflation of the past 15 years as well as revitalizing the shrinking economy' (Suzuki, 2013, pp. 70$71)$.

The narrative of the Tokyo 2020 bid invoked fond memories of Tokyo 1964 when the city displayed its youthfulness to the world, satisfied that its message of 
peace provided the foundation for a new legacy. Now that pacifism was established, new signifiers of Japan's technologically-advanced uniqueness and the national quest for sustainability were employed to reiterate the message of Tokyo reclaiming international pre-eminence by providing a benchmark for a sustainable future. The idea was for Tokyo to stress its maturity as a global city at the forefront of the sustainability movement in an effort at '[increasing] international awareness of the quality, brand power, and safety of Japanese products and services, and boost expenditure on food, cultural experience, and other leisure-related consumption' (Osada, et al, 2016, p. 11). Still, there were hints of Asian Otherness in that the Beijing Olympics prompted opinion leaders to warn Tokyo 2020 organisers not to repeat the mistakes of Beijing 2008.

By now, the Western Other has been further diluted into a more nebulous, generalised, Otherness, while the Asian Otherness has been further subdued into recasting Asia as a rival to Tokyo's status as an attractive global city. Yet, dual Otherness was still seen as an asset. TOCOG's (2013, p. 5) Candidature File submitted to the IOC in January 2013 pointed out that Tokyo was best equipped to enlist 'Japan's unique culture and characteristics' to produce 'global trends', pointing out that Tokyo as a 'global city' is able to contribute a 'value added', including Tokyo 2020's 'compact' scale, as well as 'education and awareness programmes'. TOCOG (2013, p. 6) explicitly outlined how 'Japanese culture is unique' with a coexistence of old and new, where 'tradition and dignity fused with innovation and high-tech knowhow', providing an opportunity for 'Japan and the world to forge new

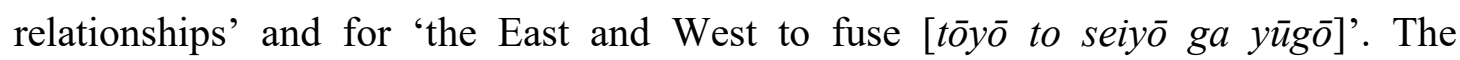
Governor of Tokyo, Inose Naoki, admitted that the delegates attending the 2013 Buenos Aires IOC meeting felt that 'showcasing a Japan that was un-Japanese would 
be most effective' (Mizuide, 2016, pp. 81-82). The presentation was un-Japanese given the speech by Princess Takamado, who 'seamlessly switched between her fluent French and then English', along with an elucidation of Japanese omotenashi ('hospitality') by a French-Japanese TV presenter, Takigawa Christel, speaking with her 'English with a French accent' (Ikei, 2016, p. 29).

The past and tradition were also invoked to stress Japanese uniqueness. The president of the Tokyo Organising Committee and a former prime minister, Mori Yoshirō (2013, p. 130) wrote in November 2013 that 'our victory is the first time since the Russo-Japanese War in which the nation united as one', invoking a historical signifier of what purportedly distinguished Japan from the West, and ultimately Asia. Former Japanese athletes echoed similar sentiments. Tamesue Dai (Yamaguchi and Tamesue, 2015, p. 199), a former track athlete, suggested that the 2020 Olympics should herald an opportunity for Japan to reclaim its traditional values in front of an international audience. For him, Tokyo 2020 needs to be a spectacle in reclaiming Japanese uniqueness (dokuji-sei), and to practice the unique Japanese art of hospitality (omotenashi) (Yamaguchi and Tamesue, 2015, p. 199).

Prime Minister Abe immediately identified the Olympics as a vital tool for reconstruction, as well as a means for Japan to reassert its purported uniqueness. The Japanese government hosted a banquet in March 2013 to commemorate the $50^{\text {th }}$ anniversary of Tokyo 1964, as part of the Tokyo 2020 campaign. Here, Abe told guests that Tokyo will showcase resurrection 'from destruction to a new vitality', pointing out that 'everyone should be given a second chance' (Kantei, 2013a). For Abe, the Olympics symbolise an opportunity for the state to proclaim its Japaneseness and reaffirm national dignity, while simultaneously kick-starting the post-3/11 economy by stimulating reconstruction efforts. Abe hoped that Tokyo 2020 will send 
a clear message that a proud Japan, with its purportedly unique and attractive culture, is now open for business. Abe stated at a meeting of organisers in October 2014 that the Olympics will be a 'celebration to reclaim our country' (Kantei, 2014a), and on the same day, he talked of the need to 'resurrect our country so that we can contribute at the heart of the world' (Kantei, 2014b). Abe wanted the Olympics to exhibit Japan's glorious resurrection, stating in June 2015 after the decision was made to host the 2020 Games, that 'Japan will host the Games that shines to the world [sekai ni mukete kagayaku]' (Kantei, 2015b). Abe repeated the theme of reconstruction at a meeting in July 2015, telling the participants that the Olympics will be an opportunity 'to show Japan's reconstruction efforts' (Kantei, 2015a), and in November 2015, Abe told the organisers that the Games are not only about reconstruction, but also 'an opportunity to let the country and the world become aware of the attractiveness [miryoku] of Japan's diverse culture in 2020' (Kantei, 2015c). Abe reiterated in October 2016 that the Olympics are a chance to 'let the world know of Japan's diverse culture' (Kantei, 2016), and in April 2017, he told a meeting that the Games 'will provide the much needed impetus for reconstruction and regional revitalisation' (Kantei, 2017a). He repeated the idea in February 2018, stating that the Olympics 'will show the world how we have recovered from the disaster' (Kantei, 2018). Hence, despite the nationalist language, dual Otherness was steadily being eclipsed by the theme of sustainability and reconstruction. And the imperative of infrastructure investment proved controversial, eliciting another layer of Otherness to emerge at a different, primarily domestic, level.

\section{Discord from Abroad and at Home}


Now that Tokyo 2020 is a reality, there are sceptical voices from Asia questioning the very premise: whether Tokyo - and Japan — is fit to be a host. While The Straits Times (2017) reported in February 2017 that the organisers have decided to seek the 'support' of anime characters as a 'strategy to lure more tourists to its shores using manga and anime', there remains a lingering anxiety over the fallout from Fukushima (Agence France-Presse and Reuters, 2013). Simultaneously, there is a concern over latent xenophobia in Japan - another stark reminder of Japanese condescension towards Asia. South China Morning Post reports on the use of racial profiling by the Japanese police, with concerns raised over the purportedly 'normalized standard procedure with Japan's police' in using 'racialized caricature' (Ryall, 2016). Furthermore, the Post reports on the online petition, mainly by South Korean residents, who called on the IOC not to select Tokyo due to Japan's failure to recognise 'the massive and inhumane atrocities' committed in Asia during the War (Li, 2013). This was another reminder that the organisers' story of Japan's focus on the future did not seem to travel well in the rest of Asia. Furthermore, Tokyo 2020's emphasis on high-tech invites an awkward response from Asia. As the New Straits Times (Associated Press, 2016a, 2016b) reports, while the Olympics will help boost the stagnant economy, the organisers' stated aim of revitalising the economy encounters an ironic twist. The Times reveals Japan's resistance to immigration amidst the challenges of population decline as a facet of Japan's racialised worldview. And in quoting a Japanese economist, Kobayashi Shinichirō, the report highlights another irony: that 'Japan is good at working towards a goal like the Olympics because of a strong work ethic and organizational ability but hasn't succeeded at reshaping its economy' (Associated Press, 2017). Hence, the Japanese emphasis on its unique characteristics sits uncomfortably with the Asian images of Japan. 
But what is more striking is the emergence of domestic discontent: the prospect of Tokyo attracting all the attention and infrastructure investments means that the regions are being side-lined, having to compete for capital and labour with Tokyo. What emerges is a third, domestic layer of Otherness. Saiki (2015, p. 34) warns of how the sole focus on Tokyo undermines the rhetoric of 'All Japan' once the incongruities of infrastructure investments become apparent. Nakamura Yūji (2018a, pp. 5-6) suggests that, even if the periphery was enlisted in appealing to the world that Japan had revived since $3 / 11$, the regions need to prioritise rebuilding rather than partaking in the national Olympics celebrations - almost to the extent that the plight of the rural areas were exploited in a bid to justify infrastructure investments around Tokyo to win the Olympics. Nakamura (2018b, pp. 2-4) also raises the controversy over the Naganuma boat race course in Miyagi Prefecture which TOCOG earmarked for rowing competitions, ostensibly to show that organisers are mindful of revitalising the regions. However, the proposal was shelved due to cost as well as logistics prompting the regional governments in Miyagi and beyond to feel that they were barred from the decision-making process, aggravating the periphery's scepticism towards TOCOG (Nakamura, 2018b, p. 9). Furthermore, while Tokyo 2020 is seen as enriching regional economies (Kobayashi, 2015; Matsumoto, 2016), a business weekly, Nikkei Business, found in November 2013 that residents in the periphery felt that Tokyo 2020 was 'the Olympics in Tokyo' and that the Games had nothing to do with them (Somehara, 2013).

Simultaneously, concerns over the aftermath of the Fukushima Daiichi nuclear disaster linger. A civic group, No Olympics 2020 (2013) argues that the priority should be to clean up after the nuclear contamination, rather than spending on an expensive extravaganza. The group also raises concerns with the nationalistic 
dimensions of the Olympics, arguing that Tokyo 2020 is nothing but an interstate rivalry in disguise (No Olympics 2020, 2013), associating the Games with violence. The group is not alone in making such a connection. A journalist, Morita Hiroyuki (2016), starts out by outlining his concern over the Fukushima Daiichi disaster, but then goes on to claim that those who oppose the Olympics are treated as 'traitors' (hikokumin); and he feels 'suffocated' witnessing the heightened sense of nationalism. Morita (2018) is also puzzled by the slogan, 'Japan [Nippon] needs the power of this dream', particularly the appropriation of the term, Nippon, rather than Nihon, let alone Tokyo. For Morita, the very sound of Nippon evokes nationalism, framing the Games as an event for the Japanese nation, not just Tokyo. A similar observation is made by another journalist, Inagaki Kensuke (2016), who feels uneasy with the jingoistic tone in Japanese media coverage of major sporting events.

Even for Tokyo, the Olympics expose a serious governance issue. An urban planner, Minohara Kei (2014, p. 354), notes that urban planning in Japan has not been successful at dispelling the image of a 'construction state' (doken kokka), making it difficult to enable an environmentally sustainable city to emerge. Azuma Hideaki (2014, p. 597) argues that the metropolitan government remains vague in its plans to transform Tokyo into a resilient city following 3/11, unable to formulate a coherent vision for earthquake-proofing the reclaimed land. Echoing this view, the journalist Murashima Takehito (2016) suggests that this is not surprising, given that satisfying the construction lobby has always been the priority in the city. Tokyo 2020 is effectively 'a fait accompli by the state', enabling the government to ignore the issues of governance, particularly over the spiralling cost (Abe, 2016, pp. 68; 71).

The organisers seem well aware of such criticisms and the potentials for derailing their preparation for Tokyo 2020. The spiralling cost of constructing the 
Olympics venues prompted organisers to change plans in an effort at seeking a cheaper alternative, including the rejection of the Naganuma boat race course. Governor Koike Yuriko insisted in October 2016 that, despite changes to the plans in which venues are mainly clustered around greater Tokyo, the 'message of "reconstruction Olympics" [fukkō gorin] remains powerful' (Nihon keizai shimbun, 2016a, p. 31). Yet, TOCOG president, Mori Yoshirō, warned that 'it is extremely difficult to reverse what has been decided at the IOC' (Nihon keizai shimbun, 2016b, p. 33). Furthermore, when Koike met IOC President Thomas Bach in October 2016, Bach insisted that rules cannot be changed; but Koike responded by pointing out that, 'since we are investing public money, [the price] must be acceptable to the Tokyoites' (Nihon keizai shimbun, 2016c, p. 3). Here again, the central concern is with Tokyo's fiscal position, rather than how the Games benefit the periphery.

The problems of cost over-runs and doubts over sustainability are not surprising for a major infrastructure project. It reflects the challenges of modern Olympics: global cities like Tokyo can exploit the economies of scale to satisfy IOC demands, and they are best equipped to tell stories of their purported uniqueness. But rising costs and questions over environmental sustainability, not to mention the possibility of cronyism, risk turning Tokyo 2020 into another case of a failed investment project (Hompo and Yagase, 2014, p. 9) revealing the limits of a top-down 'identity entrepreneurship' in which the government sought to formulate a uniquely Japanese story of Tokyo 2020 in the hope that the public would embrace the imagined Olympics community. But the government failed to forge a coherent narrative. Externally, the story was about reconstruction; while domestically, resistance to purportedly nationalistic language emerged and the sustainability agenda suffered from fiscal constraints. Furthermore, the government failed to persuade the public of 
the merits of hosting the Games. As such, the overall message was mangled (Gotō, 2014, pp. 83-84). Moreover, the Olympics as a mega project is starting to reveal fissures between Tokyo and the periphery. These controversies represent a facet of a complex and multi-layered Otherness within the Tokyo 2020 narratives.

\section{Conclusion}

The Olympic Games are opportunities for the host city to attract the world's attention to itself. The image of sport as sacred and as manifestations of fairness provides a convenient and an uncontroversial platform for the elaboration of nationalist language. For postwar Japan, Tokyo 1964 provided an opportunity for it to employ the sanctity of sport to reaffirm its pacifist credentials, along with national identity narratives that would have resembled prewar ultranationalism, had it not been for the Olympics to provide them with an acceptable outlet (Ikei, 2016; Tagsold, 2009). The narratives of Tokyo 2016 and 2020 tell stories of Japan's technological prowess in pioneering sustainable Olympics. For the Tokyo 2020 bid and organisation narratives, in particular, the imperative of reconstruction following $3 / 11$ is represented as an opportunity for Tokyo to show the world that Japan is back and everything is under control. Hence, the narratives of the Tokyo 2016 Tokyo 2020 bids and their preparation seem to depart significantly from those of the Tokyo 1940 and 1964 bids: overt emphasis on dual Otherness is now superseded by claims to high-tech skills and sustainability.

We can still see hints of dual Otherness which stipulate that Japan is unique from the West and unlike Asia. As Kōno Ichirō, Chief Director of the Japanese Sport Council suggested with respect to the Tokyo 2016 bid, 'the power of sport is an important strategic tool to show the existence of a nation. It is indisputable for 
Japanese society to raise the dignity of Japan as a nation in terms of the nation's strategy' (Shimizu, 2014, p. 612). Hence, it still makes sense for the organisers of Tokyo 2020 to construct Japanese identity narratives that distinguish Japan from the rest of the world, as well as from East Asian rivals such as China. Simultaneously, though, the IOC's sustainability agenda and the reality of hosting the 2020 Games mean that Tokyo will attract the bulk of public investment. Furthermore, Tokyo 2020 as a national project implies that critics are branded unpatriotic. The criticisms of Tokyo 2020 organisation show that the dominant narratives are far from monolithic. The multi-layeredness of Otherness in the Tokyo 2020 narratives exposes the potential paradox of modern Olympics: hosting the Games will ostensibly benefit the state as a whole, but the reality might be to accelerate regional disparities. Hence, the Olympics in a global city not only reproduces the familiar national identity narratives, but also constructs another, domestic, layer of Self/Other dichotomy pitting the host metropolis against the periphery.

Tokyo as a global city and the pressures from the IOC mean that the identity narratives of the Tokyo 2016 bid and the Tokyo 2020 bid and organisation have significantly transformed from the stories of the Tokyo 1940 and 1964 bids. The stories of Otherness in Tokyo 2020 show that they are much more complex. Modern Olympics ceased to be an outlet solely for national identity representation. Rather, the Games constitute a locus of contestation between and among multiple claims - both international and domestic — to imagined communities.

\section{Reference}


Abe K. (2016) Tokyo orinpikku josetsu: '2020-nen no Nippon' no shakai-gaku [Introduction to Tokyo Olmypics: the sociology of 'Japan in 2020'], Kwanseigakuin daigaku shkaigakubu kiyō, 123, 65-83.

Abe S. (2013) Atarshii kuni e [Towards a new country]. Tokyo: Bunshun shinsho.

Agence France-Presse and Reuters (2013, 8 September) Tokyo Celebrates an Emotional Olympics Victory, South China Morning Post. Available from: http://www.scmp.com/print/sport/other-sport/article/1306017tokyo-celebratesemotional-olympics-victory. [Accessed on 5 July 2017].

Anderson, B. (1991) Imagined Communities. London: Verso.

Associated Press (2017, February 23) Japan Worried About 2020 Problem, or Life After the Olympics, New Straits Times. Available from: http://nst.com.my/ news/2016/02/126534/japan-worried-about-2020-problem-or-life-after-olympics?d=1. [Accessed on 5 July 2017].

(2016a, August 24) (Olympics) Five things to know about Tokyo 2020, New Straits Times. Available from https://www.nst.com.my/news/2016/08/ 167971/olympics-five-things-know-about-tokyo-2020. [Accessed on 5 July 2017]. (2016b, August 22) After Rio, Olympics headed for Asian venues seen as safe, New Straits Times. Available from https://www.nst.com.my/news/2016/08 /167341/after-rio-olympics-headed-asian-venues-seen-safe. [Accessed on 5 July2017]. 
Aso, N. (2002) Sumptuous Re-past: The 1964 Tokyo Olympics Arts Festival, Positions: East Asia Cultures Critique, 10(1), 7-38.

Azuma H. (2014) Tōkyō ni okeru ibento no chikara to sono shōrai-sei [The power and future of events in Tokyo], Chigaku zasshi, 123(4), 587-99.

Bale, J. (1986) Sport and National Identity: A Geographical View, The International Journal of the History of Sport, 3(1), 18-41.

Brubaker, R., and Cooper F. (2000) Beyond 'Identity', Theory and Society, 29(1), 147.

Campbell, D. (1998) Writing Security (Rev. Ed.). Manchester: Manchester University Press.

Collins, S. (2007a) Introduction: 1940 Tokyo and Asian Olympics in the Olympics Movement, The International Journal of the History of Sport, 24(8), 955-76.

(2007b) The 1940 Olympics: Imperial Commemoration and Diplomacy, The International Journal of the History of Sport, 24(8), 977-1002.

(2007c) East and West: Confrontational Diplomacy, The International Journal of the History of Sport, 24(8), 1003-41. 
(2006) Conflicts of 1930s Japanese Olympic Diplomacy in Universalizing the Olympic Movement, The Journal of the History of Sport, 23(7), 1128-51.

Dower, J. (1999) Embracing Defeat: Japan in the Wake of World War II. London: Allen Lane the Penguin Press.

Gotō H. (2014) Shimbun-hōdō kara mita 2020-nen gorin shōchi [Observing 2020 Olympics through newspaper reports], Biwako seikei supōtsu daigaku kenkyū kiyō, 11, $81-87$

Hara E. (2015, August 9) Kono mama dewa Chūgoku no ninomai: shin-kokuritsu kyōgijō no arata na mondai 'gorin-go' no bijon ga nai! [Don't repeat Chinese lessons: no post-Olympic vision for the new sport stadium], Gendai bijinesu. Available at http://gendai.ismedia.jp/articles/-/44792 [Accessed on 25 August 2015].

Hompo Y. and Yagasaki N. (2014) Kako no orinpikku, pararinpikku no keiken wo fumaeta 2020 Tōkyō orinpikku, pararinpikku wo keiki to shita inbaundo shinkō-saku ni kansuru ichi kōan [Learning from the past Olympics and ideas about using 2020 Tokyo Olympics and Paralympics to boost ibound tourism], Shuto daigaku kankōkagaku kenkyū, 8, 3-11.

Horne, J., and Manzenreiter, W. (2012) Olympic Tales from The East: Tokyo 1964, Seoul 1988 and Beijing 2008, in Lenskyj, H. J., and Wagg, S. (Eds.) The Palgrave Handbook of Olympic Studies. London: Palgrave, pp. 103-119. 
(2004) Accounting for Mega-Events: Forecast and Actual Impacts of the 2002 Football World Cup Finals on the Host Countries Japan/Korea, International Review for the Sociology of Sport 39(2), 187-203.

Houlihan, B. (1997) Sport, National Identity and Public Policy, Nations and Nationalism 3(1), 113-37.

Inagaki K. (2016, July 14) Mujun made nomikonde iku gorin no maryoku [The magic of Olympics swallowing contradictions], WebRonza. Available at http://webronza.asahi.com/journalism/articles/2016070300002.html. [Accessed on 5 July 2017].

Inose N. (2011) Naze 'Tōkyō orinpikku' nanoka: kankyō wo jūshi shita senshinkokugata moderu wo tsukuru [Why Tokyo Olumpics? Constructing a environmentallyconscious model for a developed economy]. Available at www.nikkeibp.co.jp/ style/biz/inose/080617_45th/index/html. [Accessed on 15 April 2011].

Ikei M. (2016) Orinpikku to Nippon gaikō: Mittsu no 'Tōkyō orinpikku' wo chūshin ni [Olympic and Japanese diplomacy: focus on the 'three Olympics'], Hoggaku kenkyū, 89(4), 1-34.

(2013, November) Gorin shōchi ni shōri shita ōru-Japan gaikō [How All Japan won the Olympics campaign], Gaikō, 72-77. 
(2012) Katarare nakatta sengo Nippon gaikō [The silences surrounding postwar Japanese diplomacy]. Tokyo: Keiō gijuku daigaku shuppankai.

Kantei (2018, February 6) Dai 1-kai Tōkyō orinpiiku kyōgi taikai, Tokyo pararinpikku kyōgi taikai susihin-honbu deno sōri aisatsu [Prime minister's greetings at first meeting of the Tokyo Olympics Paralympics organising committee]. Available at https://www.kantei.go.jp/jp/headline/tokyo2020/dai1kaigo_aisatsu.html. [Accessed on 11 April 2018].

(2017a, April 4) Tōkyō orinpkku kyōgi taikai, Tōkyō pararinpikku kyōgi taikai suishin honbu [Tokyo Olympics Paralympics organising headquarters]. Available at https://www.kantei.go.jp/jp/97_abe/actions/201704/04olypara.htm. [Accessed on 11 April 2018].

(2016, October 7) Tōkyō orinpikku kyōgi taikai, Tōkyō parainpikku kyōgi taikai suishin honbu [Tokyo Olympics Paralympics organising headquarters]. Available at https://www.kantei.go.jp/jp/97_abe/actions/201610/07olypara.html. [Accessed on 11 April 2018].

(2015a, July 24) Tōkyō orinpikku kyōgi taikai, Tōkyō parainpikku kyōgi taikai suishin honbu [Tokyo Olympics Paralympics organising headquarters]. Available at https://www.kantei.go.jp/jp/97_abe/actions/201507/24olypara.html. [Accessed on 11 April 2018]. 
(2015b, June 26) Tōkyō orinpikku kyōgi taikai, Tōkyō parainpikku kyōgi

taikai suishin honbu jimukyoku kanban kake oyobi kunji [Remarks at inauguration of Tokyo Olympics Paralympics organising headquarters]. Available at https://www.kantei.go.jp/jp/97_abe/actions/201506/26oripala.html. [Accessed on 11 April 2018].

(2015c, November 27) Tōkyō orinpikku kyōgi taikai, Tōkyō parainpikku kyōgi taikai suishin honbu [Tokyo Olympics Paralympics organising headquarters]. Available at https://www.kantei.go.jp/jp/97_abe/actions/201511/27olypara.html. [Accessed on 11 April 2018].

(2014b, October 10) 1964-nen Tōkyō orinpikku pararinpkku 50-shūnen kinen shukuga-kai $\left[50^{\text {th }}\right.$ anniversary celebrations commemorating the 1964 Tokyo Olympics and Paralympics]. Available at https://www.kantei.go.jp/jp/96_abe/ actions/201410/10_1964oly_para_shukugakai.html. [Accessed on 11 April 2018]. (2014a, October 10) Tōkyō orinpikku pararinpikku kyōgi taikai soshiki iinkai komon-kaigi [Tokyo Olympics Paralympics organising committee advisors' meeting]. Available at https://www.kantei.go.jp/jp/96_abe/actions/201410/10oly_para_komon _kaigi.html. [Accessed on 11 April 2018].

(2013a, March 6) Kōshiki kangei: Tōkyō orinpikku kaisai 50-nen kinen yūshoku-kai [Official celebration: Dinner celebrating the $50^{\text {th }}$ anniversary of Tokyo Olympics]. Available at https://www.kantei.go.jp/jp/96_abe/actions/201308/23tokyo_ shouchi.html. [Accessed on 11 April 2018]. 
(2013b, August 23) 2020-nen Tōkyō orinpikku pararinpikku shōchi shutsujinshiki [2020 Tokyo Olympics Paralympics bid mobilisation celebrations]. Available at https://www.kantei.go.jp/jp/96_abe/actions/201308/23tokyo_shouchi.html. [Accessed on 11 April 2018].

Kelly, W.W. (2011) East Asian Olympics, Beijing 2008, and the Globalisation of Sport, The International Journal of the History of Sport, 28(16) 2261-70.

(2009) Asia Pride, China Fear, Tokyo Anxiety: Japan Looks Back at 2008

Beijing and Forward to 2012 London and 2016 Tokyo, The Asia-Pacific Journal, 7(5) $1-12$

Kietlinski, R. (2011) One World One Dream? Twenty-first Century Japanese Perspectives on Hosting the Olympic Games, Sport in Society, 14(4), 454-65.

Kobayashi Y (2015) The Need for 'Rebuilding Tokyo' with the 2020 Tokyo Olmpics as Impetus, NRI Papers, 200, 1-12.

Koshiisi M. (2008) 'Tōkyō 2016 rogo' nit suite [On Tokyo 2016 logo], Dezain riron, $53,17-30$.

Li, A. (2013) Petition Tries to Thwart Tokyo's Olympic Bid Over War Crimes, South China Morning Post, 4 July. Available at http://www/scmp.com/print/news/asia/ 
article/1275178/petition-tries-thwart-tokyos-olympics-bid-over-war-crimes [Accessed on 22 February 2017].

Maguire, J. A. (2011) Globalization, Sport and National Identities, Sport in Society, 14(7-8), 978-993.

(1994) Sport, Identity Politics, and Globalization: Diminishing Contrasts and Increasing Varieties, Sociology of Sport Journal, 11(4), 398-427.

Manzenreiter, W. (2006) Sport Spectacles, Uniformities and the Search for Identity in Late Modern Japan, The Sociological Review, 54(2) suppl., 144-59.

Matsumoto Y (2016) Orinppiku regashī to chiiki kassei-ka [Olympic legacy and regional reviatlisation], Fuskushima no shinro, September, pp. 32-37.

Morita H (2018, April 4) 2-nengo ni sematta Tokyo gorin de kangaetai koredakemo mondai [Issues we need to consider for Tokyo Olympics two years from now], Web Ronza. Available from http://webronza.asahi.com/politics/articles/20180402 00002.html?returl=http://webronza.asahi.com/politics/articles/2018040200002.html\& code $=101 \mathrm{WRA}$. [Accessed on 10 April 2018].

(2016, October 29) Tōkyō gorin, hantai-shitemo iidesuka? [Can I oppose Tokyo Olympics?], Gendai bijinesu. Available from http://gendai.ismedia.jp/articles//50050. [Accessed on 5 July 2017]. 
Mizuide K. (2016) 2020-nen Tōkyō Orinpikku, Pararinpikku kaisai kettei to tasha [2020 Tokyo Olympics and Paralympics and the Other], Supōtsu shakaigaku kenkyū, 24(1), 79-92.

Mori Y. (2013, November) IOC sōkai okiretsu na 'jōhōsen' no shōri [Winning the fierce information battle at the IOC meeting], Bungei shunjū, 124-33.

Murashima T. (2016, February) Futatsu no 'riken' no shōtai [Revealing the two vested interests], Sekai, 54-60.

Nakano K. (2015) Ukei-ka suru Nippon seiji [The right-wing turn in Japanese politics]. Tokyo: Iwanami shinsho.

Nakamura Y (2018a) 2020-nen Tōkyō gorin wo meguru hihan to kosuto-futan: setsumei sekinin no arikata [The Criticism of the 2020 Tokyo Olympics Games and the Cost-burden: What the Accountability Should Be, Chiiki dezain kagaku, 4: pp. 122.

(2018b) 2020-nen Tokyo gorin no kyogi-shisetsu to hiyo-futan wo meguru kankeisosiki-kan no masatsu to chosei: taikai soshiki iinkai, Tokyo-to, seifu, kyogi dantai, shiho jichitai [Friction and Coordination among Stakeholdrs concerning Athletic Facilities and Expenditures for the 2020 Tokyo Olympic Games: Organising Committee, Tokyo Metropolis, Central Government, Athletic Organization and Local Governments], Chiiki dezain kagaku, 2: pp. 1-14. 
Niehaus, A., and Tagsold, C. (2011) Remembering the Glory Days of the Nation: Sport as Lieu de Mémoire in Japan, Sport in Society, 14(4), 403-11.

Nihon keizai shimbun (2016a, October 16) Koike chiji, Miyagi no bōto-kaijō shisatsu: ken, yasu-agari apīru [Koike visits Miyagi boat venue: prefecture to appeal low cost], Nihon keizai shimbun, p. 31.

(2016b, October 18) Gorin kaijō chakuchi-ten saguru [Olympic venues in search of landing point], Nihon keizai shimbun, p. 33.

(2016c, October 19) Gorin kaijō minaoshi de ōshū [Discussion over changes to Olympic venues], Nihon keizai shimbun, p. 3.

Nishiyama T. (2015) Hanrei-teki media ibento to shite no 2020 Tokyo orinpikku pararinpikku taika no yukue ni tsuite [The direction of 2020 Tokyo Olympics Paralympics as an exemplar media event], Masu-komyunikēshon kenkyū, 86, 2-17.

No Olympics 2020 (2013), 2020-nen Tōkyō ni Orinpikku wa irimasen [We don't need 2020 Olympics in Tokyo], Available from: https://hangorin.tumblr.com/post/56054121488/20202020 年東京にオリンピックは いりません. [Accessed on 5 July 2017].

Ōno S. (2014, November) Tōkyō orinpikku ni muketa senryaku PR no arikata [The PR strategy for Tokyo Olympics], Kaigai jijō, 55-65. 
Osada, M., et al. (2016, January) Economic Impact of the Tokyo 2020 Olympic Games, BOJ Reports and Research Papers, Tokyo: Bank of Japan.

Porpora, D. V. (1997) The Caterpillar's Question: Contesting Anti-Humanism's Contentions, Journal for the Theory of Social Behaviour, 27 (2/3): 243-63.

Ryall, J. (2016, June 30) Is this Poster Urging Japanese to Report Foreign visitors to Police Racist?, South China Morning Post. Available from: http://www/scmp. com/print/news/asia/east-asia/article/1983438/poster-urging-japanese-report-foreignvisitors-police-racist. [Accessed on 22 February 2017].

Saiki T. (2015) 2020 Tōkyō orinpikku kyōgikai [The 2020 Tokyo Olympic Games], Supōtsu shakaigaku kenkyū, 23(2), 25-44.

Sassen, S. (2016) The Global City: Enabling Economic Intrermediation and Bearing Its Costs, City and Community, 15(2), 97-108.

(1995) The State and The Global City: Notes Towards a Conception of PlaceCentered Governance, Competition and Change, 1(1), 31-50.

Sell, C. M. (2007) The 1940 Tokyo Games: The Games the Never Were - The Art Contests and the XIIth Olympiad, Journal of Olympic History, 15(2), 40-49.

Shimizu, S. (2014) Tokyo-bidding for the Olympics and the discrepancies of nationalism, The International Journal of the History of Sport, 31(6), 601-17. 
Somehara M. (2013, November 26) Tokyo gorin ni chiho wa tsumtai? [Regions are cool towards Tokyo Olympics?], Nikkei Business Online. Available at: https://business.nikkeibp.co.jp/article/opinion/20131121/256168/. Accessed on 17 October 2018 .

Somers, M. R. and Gibson, G. D. (1994) Reclaiming the Epistemological 'Other': Narrative and the Social Construction of Identity, in Calhoun, C. (ed) Social Theory and the Politics of Identity. Oxford: Blackwell, pp. 37-99.

Suzuki Y. (2013, November) 'Abe senryaku' ni kumikomareta Tōkyō gorin [Tokyo Olympics as part of Abe strategy], Gaikō, 68-71.

Spobiz (2011) Tōkyō kara atarashii orinpikku-zo wo: Nippon supōtsu-kai wo henkaku shi, yutakani hagukumu chansu ni [New Olympics from Tokyo: A chance to reform and nurture Japanese sports]. Available at www.spobiz.net/info/page-spoleader0101.php/ [Accessed on 25 April 2011].

The Straits Times (2017, February 2), Olympics: Anime Characters, Including Naruto and Dragon Ball's Son Goku, Turn Ambassadors for Tokyo 2020, The Straits Times. Available from http:/www.straitstimes.com/sport/olympics-anime-charactersincluding-naruto-and-dragon-balls-son-goku-turn-ambassadors-for. [Accessed on 5 July 2017]. 
Tagsold, C. (2010) Modernity, Space and National Representation at the Tokyo Olympics 1964, Urban History, 37(2), 289-300.

(2009) The 1964 Tokyo Olympics as Political Games, The Asia-Pacific Journal, 7(3) 1-7.

Taniguchi G. (1997) Hinomaru to orinpikku [The Japanese flag and Olympics]. Tokyo: Bungei shunjū.

TOCOG (2013) Rikkōho fairu Vol. 1 [Candidature file Vol. 1]. Tokyo: TOCOG. (2010) 2016-nen Orinpikku pararinpikku kyogi taikai shochi hokokusho [The Report on the 2016 Tokyo Olympics and Paralympics Campaign]. Tokyo: TOCOG.

Tourism Agency (2014) Kankō hakusho [Tourism White Paper]. Tokyo: Tourism Agency.

Uesugi T. (2013, November) Ishihara Shintarō wa 'omoshiroi' to sokudan shita [Ishihara Shintaro agreed instantaneously, saying 'that is interesting'], Bungei shunjū, $134-42$.

Ward, T. (2009) Sport and National Identity, Soccer \& Society, 10(5), 518-31.

Yamaguchi K. and Tamesue D. (2015, November) Warera orinpian, 2020-nen e no yabō [We are Olympians: ambitions for the 2020], Chīo kōron, 192-99. 
Yyuan, S. (2013), A Miraculous Revitalization of Japan? A Comparative Analysis of the 1964 Tokyo Olympics Games, the Failed 2016 Host City Bid and the Successful 2020 Bid, Asia Pacific Journal of Sport and Social Science, 2(3), 198-213. 